\title{
SPECIFICS OF EVALUATING THE EFFICIENCY OF DEVELOPMENT INVESTMENT PROJECTS
}

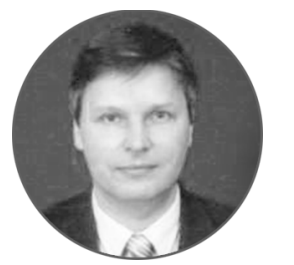

Sergei A. FILIN

Plekhanov Russian University of Economics, Moscow, Russian Federation

Filin.SA@rea.ru

Corresponding author

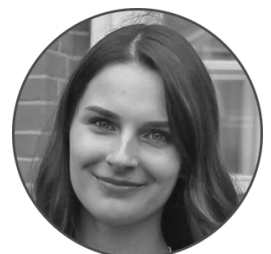

\section{Vera A. MARUSHKINA}

Plekhanov Russian University of Economics, Moscow, Russian Federation maruvera@yandex.ru

\section{Article history:}

Received 15 August 2017

Received in revised form

14 September 2017

Accepted 10 October 2017

Translated 14 May 2018

Available online 27 June 2018

JEL classification: G24, 016

Keywords: real estate market, development, developer project, efficiency evaluation, residential property

\begin{abstract}
Importance The research identifies the specifics of evaluating the efficiency of development investment projects. Objectives We outline an algorithm for evaluating the efficiency of development investment projects, formalize the process and give recommendations for improving the evaluation process in line with the specifics of development projects and real estate market.

Methods The article employs methods of logic study, forecasting, analysis and synthesis through a systems and information processing approach. The article provides algorithms, including the one for formalizing and evaluating the efficiency of development projects through the specifics of their performance and real estate market.

Results We showcase the way the specifics of evaluating the efficiency of development investment projects directly relates to the main trends in the real estate development in Moscow so as to make an evaluation more accurate and unbiased. We propose a formalized algorithm for evaluating whether development construction and investment projects are effectively implemented, and provide our recommendations for improving the process.

Conclusions and Relevance The formalized algorithm for evaluating the developer project efficiency helps to make informed managerial decisions on investment and project performance and mitigate weaknesses of traditional methods as if each of them was used separately.
\end{abstract}

The editor-in-charge of this article was Irina M. Vechkanova Authorized translation by Irina M. Vechkanova

\section{Introduction}

Nowadays a system of social relations is indispensable without real estate, which determines the way

${ }^{\dagger}$ For the source article, please refer to: Филин С.А., Марушкина В.А. Особенности оценки эффективности инвестиционных девелоперских проектов. Национальные интересы: приоритеты и безопасность. 2017. Т. 13. № 11. С. 2112 - 2131. URL: https://doi.org/10.24891/ni.13.11.2112 individuals behave in different aspects of their life. Real estate is the central element of market relations, with its constituents being the main commodity satisfying a variety of personal needs and income-bearing tangible capital [1].

Growth in the national economy or an economic entity means an increase in economic capabilities, which are fostered by investment in new construction projects, 
retrofitting and re-engineering of operational enterprises ${ }^{1}$. As market actors sought for investment in real estate ${ }^{2}$, including investment in residential property [2], this led to the origination of development as a special type of business [3], investment and construction activities related to real estate development projects.

According to the contemporary dictionary of economics [4], development stands for management of business, construction, real estate in pursuit of appreciation of items and benefits from them by assessing the instability, risks, successful instances of capital expenditures and seizing growth opportunities.

As set forth in Town and Country Planning Act 1990, "development" means the carrying out of building, engineering, mining or other operations in, on, over or under land, or the making of any material change in the use of any buildings or other land.

According to I.S. Artsybashev [5], development represents the work for development of territories and refurbishment of real estate items in order to increase their market property and competitiveness.

As A.Yu. Dudchenko puts $i^{3}{ }^{3}$, development refers to a set of organizational, factual and legal actions as part of business activities in construction so as to create and replace real estate items and subsequently derive profit from them. From economic perspectives, development can be viewed as work pursuing the creation and transformation of real estate items and increase in their value. The work is intended to develop various investment projects for construction ${ }^{4}$.

There are two types of development in economically advanced countries, 1) moderate (fee-development) implying that the developer abstains from any financial risks, 2) risky (speculative development) implying that the developer constructs commercial property as the sole organizer of the project, undertakes all the risks in case of the project failure. There also exist certain types of development by type of real estate

\footnotetext{
${ }^{1}$ Teplova T.V. Investitsii [Investment]. Moscow, Yurait Publ., 2012, $724 \mathrm{p}$.

${ }^{2}$ Marushkina V.A. [Investment in the real estate market]. Nauchnyi obozrevatel' = Scientific Reviewer, 2017, no. 5, pp. 13-15. (In Russ.)

${ }^{3}$ Dudchenko A.Yu. [Legal regulation of development]. Politematicheskii zhurnal Kubanskogo gosudarstvennogo agrarnogo universiteta, 2014, no. 100, pp. 1-7. (In Russ.) URL: http://ej.kubagro.ru/2014/06/pdf/34.pdf

${ }^{4}$ Gorfinkel' V.Ya. Ekonomika predpriyatiya [Economics of the enterprise]. Moscow, YUNITI-DANA Publ., 2013, 664 p.
}

item, which is the focus of the developer's activities, i.e. residential real estate, commercial real estate, real estate for shopping, entertainment and recreation, warehousing, industrial production, social and cultural purposes, land (land plots) ${ }^{5}$.

Development constitutes a system intended for management of investment and construction projects. Based on reasonable management of project resources, developers practice a holistic approach to implementing and provisioning the project, including the sale of the finished project [6-8].

Currently, the term "development" has two types of usage in Russia. First, it refers to real estate development [9]. Second, the concise variant "development" has similar meaning.

As part of the development, developers address an array of coherent issues. Therefore, the process can be split into interim streams. Fig. 1 depicts the model for business processes in development.

Generally, a development project can be subdivided into three main phases, i.e. conceptual, project organization and construction. However, H. Behrens, M. Vay, A. Frey and others point out the five main phases of development project. Each of the phases can be split into several interim steps [10]:

1) outlining the real estate development concept [11] and preliminary project review, (a) setting up development goals and respective algorithm; (b) articulating the main development strategy; (c) market research and determination of the suitable location for the project;

2) evaluation of the location and feasibility study of the project, (a) analysis of the demand and physical feasibility of the project; (b) preliminary consultation with regulatory authorities; (c) forecasting of the probable position of other stakeholders; (d) evaluation of the financial payback probability;

3) project design and evaluation, (a) developer's team building; (b) project business planning; (c) engineering, estimation of costs and project efficiency assessment; (d) project coordination and approval with statutory controllers; (e) project adjustments, if needed, and obtaining of final permits;

\footnotetext{
${ }^{5}$ Marushkina V.A. [Development: Substance, types and legal principles of regulation]. Zhurnal nauchnykh i prikladnykh issledovanii = Journal of Scientific and Applied Researches, 2017, no. 4, pp. 41-42. (In Russ.)
}

Please cite this article as: Filin S.A., Marushkina V.A. Specifics of Evaluating the Efficiency of Development Investment Projects. 
4) conclusion of contracts and construction, (a) appointment of the contractor and contractual arrangements; (b) setting up the system for interactions of project participants; (c) setting up the system for control over the project progress;

5) marketing, management and usage of results: (a) determination of the period, method and personnel for a marketing campaign; (b) preservation and security of the project site; (c) analysis and rearrangement of sales agents' activity, if appropriate; (d) project cash flow management.

These phases may follow one by one or be concurrent. In fact, the above constituents of development projects should be regarded as steps unraveling various aspects of their performance. Sometimes some of the processes, which, say, concern marketing and management of cash flows, are not viewed as a separate phase.

The making of investment decisions becomes complicated due to a set of methods used to evaluate development projects, which generally requires or define its investment attractiveness and efficiency ${ }^{6}$. Professional evaluation of a development project enables investors and developers to avoid project errors and get as much return on investment as possible ${ }^{7}$.

Thus, modified so to evaluate development projects, the Capital Asset Pricing Model (CAPM) helps to forecast the relationship between risks associated with an asset and expected return on the asset. For example, the following formula is used to assess the required rate of return on project or $R$-company, i.e. the cost of equity, as per the CAPM:

$R=K R F+\beta(K M-K R F)$,

where $K R F$ is a risk-free profit margin;

$K M$ is average market margin (expected profit margin in the market as a whole);

\footnotetext{
${ }^{6}$ Effektivnost' investitsionnogo proekta - kategoriya, otrazhayushchaya sootvetstvie proekta tselyam i interesam ego uchastnikov i vyrazhaemaya sootvetstvuyushchei sistemoi pokazatelei. Metodicheskie rekomendatsii po otsenke effektivnosti investitsionnykh proektov [Investment project efficiency is a category reflecting the correspondence of the project and objectives and interests of its stakeholders and constituting the respective set of indicators. Methodological guidelines for evaluation of investment projects efficiency]. Moscow, National Institute of Economics Publ., 2008. URL: http://niec.ru/Met/project03redMR.pdf (In Russ.)

${ }^{7}$ Teplova T.V. Investitsii [Investment]. Moscow, Yurait Publ., 2012, p. 14.
}

Please cite this article as: Filin S.A., Marushkina V.A. Specifics of Evaluating the Efficiency of Development Investment Projects. $\beta$ is a beta coefficient of security assessed in line with the real estate investment risk.

As the model provides for, investors should pursue more substantial profits from assets with higher risk exposure.

The CAPM is difficult to apply using the formula (1) since there should be $\beta$ assessed, which would be formed to keep track of the systematic risk and for purposes of stock markets. In this case, $\beta$ may serve to assess changes in the return on real estate items constructed and commissioned.

What complicates the use of CAPM in the real estate market is that the return hardly correlates with the return on financial indices, being almost zero. It signifies that $\beta$ of real estate will also approximate zero, thus causing the underestimation of the cost of equity. This aspect grows even more onerous in Russia since there is no generally accepted market index of real estate. Furthermore, Russia lacks a leading organization or department that would able to collect data and form such an index. CAPM does not account for distinctions of the real estate market.

As part of real estate appraisal procedures, investors often resort to the income approach. It implies that the value of real estate, including capital, shall correspond with the current quality and amount of income, which the real estate can generate:

$V=I / R$,

where $V$ is the real estate value;

$I$ is expected income from real estate;

$R$ is the capitalization rate (the rate of return on investment in a real estate item as expected by the investor).

The real estate value is more often than not based on market prices. That is why the investor needs to assess the capitalization rate, including the rate of return on capital and rate of capital recovery in line with the rate of net operating income growth:

$R=I / V$.

Capitalization rate works well to compare an item to be acquired and other investment items since it allows to make comparative and approximate estimates of income from investment property and precise the scope of variants. 
The capitalization rate cannot make the investor certain of that the current income or real estate value will remain unchanged all the time. Property and respective rent may depreciate or appreciate, with expenditures concurrently rising. Therefore, capitalization rates is not in sync with the future risks.

To understand whether the development project is lucrative and efficient, groups of critical success factors are used, which determine as follows:

- attractiveness of the real estate location, including climate, geology, resources and infrastructure, demographic details, information about the city, manpower, economy, crime statistics, educational system and availability $f$ cultural institutions;

- technical feasibility of the project on the site. It refers to the quality of resources, transport accessibility, walking accessibility, surroundings and available infrastructure;

- investment project efficiency.

The development project is impossible to evaluate without assessing the potential profitable part and expenditures. The latter includes the developer's costs at each phase of the project. The profitable part of the development project is made up of income from lease of a real estate item constructed as a result of the project and revenue from its sale after the operational period.

Analyzing and assessing the profitable part of the development project, it is necessary to measure income from real estate operations as of the resale date. The real estate value as of the sale date is the principal indicator of the profitability and value of the development project However, there is a time lag between the dates of the investment project implementation and its sale.

In this respect, the indicator is computed as follows:

1) assessment of the real estate value as of the current time and specific place, characteristics of which are similar to the item to be constructed as a result of the project;

2) forecast of changes in the value of the real estate item starting from the present date up to the project completion date.

For purposes of the real estate appraisal as of the current date, traditional methods of real estate appraisal are used. They are classified into three approaches, i.e. comparative, income and cost.

However, the cost approach is not applied to assess the final market value of an item constructed as a result of the development project since analysts primarily need to understand how much the project is worth in the market.

Being a comparison of sales, the comparative (market) approach is the most common tool for appraisal purposes. The idea behind the approach is that the real estate value results from a comparison of prices for identical items, which have been sold recently, and the real estate item subject to appraisal. The approach is used due to the following reasons:

1) problematic and time-consuming collection of reliable data because the data infrastructure of the Russian real estate market leaves much to be desired, and factual prices and selling terms are often concealed to evade State duties and taxes;

2) dependence of the appraisal accuracy on the market activity and its saturation with comparable salepurchase transactions involving items like the item in question.

If there were few similar transactions, information about them is missing and the market changes rapidly, it is difficult to exactly measure the real market value of the item in question.

It is crucial to forecast expected cash flows and choose the appropriate discount rate for purposes of accurate valuation through the Discounted Cash Flow method (DCF method):

1) the future cash flow needs to be forecast. It is difficult to precisely estimate the future cash flows due to quite an unstable economic situation in Russia. Moreover, the longer the forecast period, the less accurate the estimates may be;

2) impact of risk factors on the forecast period. When the current value is measured, it is necessary to consider a probable risk associated with the future income from real estate. Whereas the probable risk is significant under the current circumstances in Russia, this influences the accuracy of the real estate valuation;

3) complicated collection of data on the rerun on similar items. Such information is usually confidential. Official information often fails to give a realistic view

Please cite this article as: Filin S.A., Marushkina V.A. Specifics of Evaluating the Efficiency of Development Investment Projects. 
of the situation. Under the current circumstances, it is problematic to verify the factual return on real estate items in Russia, thus affecting the accuracy of cost estimation;

4) it is rather challenging to measure all income constituents that might exist. Measurement of benefits from ownership of the item in case of construction real estate that provides convenient amenities and unique facilities.

Due to sanctions and global financial and economic crisis, the instability of the Russian economy mainly impedes valuation through the income approach since it blurs estimated income from construction real estate considering that the income approach strongly depends on the discounting of such income.

However, the income approach appears to be effective in case of investment valuation since it implies the comparison of income and expenses for the investment project. The approach is applicable to measurement of income-bearing real estate items, such as office and warehouse premises, trading facilities, hotels and production building, residential premises on rent.

The principle distinctions of the real estate market should be taken into account to evaluate the efficiency of projects.

1. Specifics of the market volume (through the circulation of titles). The physical immobility of real estate is one of the most crucial reasons why the real estate market offers not only real estate items, but rather titles for them, whether they are full or partial [12].

2. Specifics of the life cycle. The long life cycle of real estate items results from the durability of their creation and operation. The durability causes an uneven and complicated structure of cash flows generated by income-generating real estate.

3. Mismatch of trends in the value of real estate constituents, i.e. land and its improvements (buildings and facilities). The land tends to appreciate, while the value of buildings and facilities demonstrate some decrease. It is noteworthy that any decrease in the value of a certain real estate item stands against the opposite trend of an inflationdriven increase in the value.

4. The market and investment value of real estate are influenced by various forms of investment. The fact is seen in that multi-tiered investment is inherent in income-generating real estate, with equity- and borrowing-based investment prevailing. Moreover, the investment process may be organized differently, i.e. share in equity, time of investment. Mortgage lending is the most common method of investment. Equity and borrowings are investment, with the real estate being pledged for them. It considerably influences the usage and investment opportunities of real estate and, ultimately, its market and investment value.

5. Low liquidity. Real estate (capital construction items) is much less marketable than, say, financial assets as a result of substantial time it takes to sell the item in the market.

6. Insufficient elasticity of real estate supply. The real estate supply can significantly exceed the respective demand than in other market segments.

Revenue from sales as part of the development project can be assessed with the information on prices for real estate, rather than sales plan and area of apartment in construction by period only. Having analyzed trends in average prices in the first-time home market of New Moscow, we managed to choose a two-parametric model of Holt's exponential smoothing as a forecasting method. This is an additive model of linear growth since this time series had no seasonality and demonstrated an explicit trend. The model is expressed with a system of recurrence relations [13]:

$$
\left\{\begin{array}{l}
S_{t}=\alpha_{1} Y_{t}+\left(1-\alpha_{1}\right) \cdot\left(S_{t-1}+T_{t-1}\right) \\
T_{t}=\alpha_{2} \cdot\left(S_{t}-S_{t-1}\right)+\left(1-\alpha_{2}\right) \cdot T_{t-1} \\
\hat{Y}_{t+k}=S_{t}+k T_{t}
\end{array},\right.
$$

where $Y_{t}$ is a certain price for one square meter of residential area as of the time $t$;

$\hat{Y}_{t+k}$ is the forecast price for one square meter of residential area for $k$ steps ahead;

$S_{t}$ is a smoothed level of the series as of the $t$-time;

$T_{t}$ is a smoothed additive trend;

$a_{1}, a_{2}$ are parameters of smoothing for the level of the series and trend.

In this model the level and trend are smoothed exponentially, with different coefficients $a_{1}$ and $a_{2}$ assessed through available prices. Our forecast is based on the data series made up of average monthly prices for one square meter (147 observations) for the period 
from January 2005 through March 2017. The forecast covers the time span of 45 months (max $k=45$ ). Optimal values of coefficients $a_{1}$ and $a_{2}$ were selected using Solver, MS Excel add-in program with the specialpurpose function MSE $=\sum\left(Y_{t}-\hat{Y}_{t}\right) 2 / n \rightarrow \min$ and in line with a system of constrains:

$$
\left\{\begin{array}{l}
\alpha_{1} \geqslant 0 \\
\alpha_{2} \geqslant 0 \\
\alpha_{2} \leqslant-2+4 \alpha_{1} .
\end{array} .\right.
$$

The two opening constraints in the system (2) are ordinary in terms of this forecast method. The third one - J.Mc Clain \& L. Thomas's constraint - makes the model more stable [14]. Attempts to minimize the mean squared prediction error MSE led us to the following estimates of smoothing parameters $a_{1}=$ 1.23 and $a_{2}=0.41$. Mean Absolute Percentage Error (MAPE) was 4.293 percent meaning that the predicted results deviate from factual values by 4.3 percent on average. Fig. 2 graphically visualizes the prediction results (in values as of January of corresponding year).

According to the forecast, in January 2018, 2019 and 2020 the average price for one square meter of real estate in New Moscow will be RUB 87,625.7, RUB 90,230.6, RUB 92,835 respectively. Values predicted by the model and presented in Table 1 will be fitted to a district of the city and type of apartments (one, two, three rooms) and subsequently used to calculate revenue from sale of the apartments.

To set confidence interval for predicted values, the following formula is used as it provides for a more ample prediction interval and extended prediction horizon $k$ [13]:

$$
\hat{Y}_{\mathrm{HHT}}=\hat{Y}_{t+K} \pm t_{(N-n-1,1-\theta)}^{\mathrm{CT}} \cdot S_{p} \sqrt{k},
$$

where $\hat{Y}_{t+k}$ is point prediction as of the time $(t+k)$;

$$
t_{(N-n-1,1-\theta)}^{\mathrm{ST}} \text { is Student's } t \text {-test }\left(t_{S T}=1.977\right) ;
$$

$t$ is the time series length;

$k$ is the prediction period;

\section{$S_{p}$ is standard error of the prediction.}

There is a 95-percent probability that the price for one square meter of real estate will fall within the computed intervals in each of the periods (Fig. 3).

Once the average predicted prices are computed, adjustments shall be made for a district of the city and type of apartments (the number of rooms). The average price for one square meter of residential area in Novo-Peredelkino accounted for 0.786 of the average price for one square meter of residential area in Moscow. Besides, one square meter of a one-room apartment in Non-Peredelkino is 12.2 percent as expensive as the average one square meter of residential area in the same district (Table 2).

Therefore, the final adjustment for a one-room apartment in Kommunarka Administrative and Business Center can be presented as $0.786 \cdot 1.122=0.882$, i.e. one square meter of a one-room apartment in Kommunarka Administrative and Business Center is 12percent as cheap as the average one square meter of residential area in New Moscow. Based on the apartment sales plan and average area of apartments as envisaged in the development project, proceeds from sales are generated by period.

The discount rate shall be assessed as one of the main steps of investment project efficiency evaluation, that makes asynchronous flows comparable. The appropriate discount rate will increase the precision of the principal metrics of the project cost efficiency and make the computations adequate in terms of economic conditions of the market where the project is to be implemented. Economically, the discount rate is represented with the rate of return on investment in items with comparable risk exposure. The Weighted Average Cost of Capital model (WACC) can be used to assess the discount rate in case of mixed finance of a development project since it accounts for the amount of loan interests reducing the taxable base for purposes of income tax [15]. As per Article 269 of the RF Tax Code $^{8}$, starting from January 1, 2011, the ceiling of interests qualified as expenses equals the refinance rate of the Central Bank of Russia but multiplied 1.8 times:

$$
W A C C=W_{e} \cdot k_{e}+W_{d} \cdot k_{d} \cdot\left(1-T \cdot \frac{1,8 \cdot R_{r e f}}{R}\right),
$$

where $W_{e}$ and $W_{d}$ stand for a percentage of equity and borrowings;

$k_{e}$ and $k_{d}$ are the cost of equity and borrowings respectively;

$R_{\text {ref }}$ is the refinance rate;

\footnotetext{
${ }^{8}$ Tax Code of the Russian Federation (Par Two) of August 5, 2008 № 117-Ф3 (Edition of April 3, 2017) (as amended and supplemented and enacted as of May 4, 2017).
} 
$R$ is the interest rate on loans.

The cost of the development project equity $k_{e}$ is calculated by the formula (1). Assuming that the project corresponds with the core activity of the company, $\beta$ coefficient is considered as equal to $\beta$ coefficient of stocks held by the development project initiator, while predicted values of the capital structure adjusted for the project investment are taken as percentages. The risk-free rate is represented with the zero coupon yield rate. The average market yield was assessed by the RTS index [16] for the period of retrospective analysis from April 1, 2013 through April 1, 2017. The following formula was used:

$$
R_{m}=\sqrt[n]{\frac{R^{R T S I_{1}}}{\operatorname{RTSI}_{0}}-1},
$$

where $R T S I_{0}$ and $R T S I_{1}$ are RTS index as of the beginning and end of the period respectively;

$n$ is the number of observation periods (in this case $n=4)$.

Whereas the RTS index as of the beginning and end of the period was 832.87 and $1,423.34$ respectively, the average market rate of return $R_{m}$ accounted for 14.36 percent. Considering the financial scheme of the development project, equity and borrowings are 0.412 and 0.588 respectively. Thus, to calculate WACC using the formula (3), the following figures were obtained:

$R_{\text {ref }}=5.5 \% ; \beta=1.1 ; R_{m}=14.3 \% ; R=15.22 \%$.

$W_{e}=0.5882 ; \quad k_{d}=23.02 \% ; \quad W_{d}=0.4118 ;$ $R_{\text {ref }}=8.25 \%$.

Being measured by the formula (3), the average annual discount rate amounted to $17.208 \%$. The discount rate (quarterly) was used to discount cash flows and assess net present value of the development project.

To perform a scenario analysis of market risks, we shall determine the scope and likelihood of future events, which may modify the known trends in prediction intervals of the average prices for one square meter of real estate in New Moscow (Fig. 3).

Based on the expert method, we predefined six factors, which would be able to influence the situation in the market and prices for real estate in New Moscow:

1) increase pace of population growth, immigration;
2) betterment of economic and investment opportunities of New Moscow, geographical extension;

3) decreasing growth in average income per capita of the population (a drop in the solvent demand);

4) mid- and long-term decline in prices for oil, RUB exchange rate, investment activity and hereby prices for one square meter of real estate;

5) rising prices for oil, strengthening of the RUB exchange rate and increase in real estate prices;

6) development of mortgage lending, increasing demand for real estate.

These events are qualified as rather probable, with their effect on average prices and real estate market being generally strong.

Hereinafter we apply the simulation modeling algorithm. Each of the six events were randomly assigned to the number ranging from 1 to 100 . If the event likelihood exceeded a random number in a certain period of time, the event took place. Then we assessed the total effect on the price trend as an algebraic sum of all the effects in each of the prediction periods. These interactions were repeated many times (2,000 instances). We calculated the maximum and minimum per each period and the average effect on the price. Fig. 4 visualizes the result of simulation modeling (Monte-Carlo method).

Calculated through modeling by the Monte-Carlo method, the average prices exceed the previous forecast, indicating the predominance of optimistic scenarios in the initial set of factors. However, the gap between the minimum and maximum prices for one square meter (prediction interval) significantly grew in comparison with the initial data extrapolation (Fig. 3). Indeed, the biggest deviation of the floor and ceiling of prices from the predicted (planned) ones accounts for 24 percent and 25 percent respectively, with the uncertainty rising at the end of 2018.

After the primary trend is fitted to possible events and the three probable scenarios of real estate prices are determined, adjustments for a district and type of apartments are taken into account. Afterwards net present value of the development project is remeasured on the basis of the most probable prices 
under the scenarios. Assessed through simulation modeling, the minimum prices will be regarded as the worst case scenario, while the maximum ones will be taken as the best case scenario. The new adjusted trend in averages will be considered as an expected scenario.

To evaluate the efficiency of development projects, we propose the following algorithm:

1) collection of historical data, primary data extrapolation of prices for one square meter of residential area in accordance with the planning horizon and determination of the project cash flows;

2) identification of key internal and external factors through the sensitivity analysis, their ranking by significance;

3) expert judgment on a set of the future events, which might change the way prices behave, their likelihood and effect (measurement);

4) simulation of probabilities of some events within the given parameters of their allocation (Monte-Carlo method);

5) fitting of the primary trend to possible events, reassessment of the average (expected scenario), maximum (best case scenario) and minimum prices (worst case scenario);

6) preparation of scenarios for other key risk factors of the project and expert assignment of probabilities;

7) construction of a scenario tree, assessment of the integral indicator of net present value and analysis of results (Fig. 5).

Drawing upon the analysis, we make the following conclusions.

First, whereas unforeseen and uncontrolled changes in prices for one square meter of real estate constitute the most influential risk factor of a development project, profound techniques for scenario analysis are useful in case of this key factor. However, in case of the other factors, the intuitive logic method could be used, determining their probability and range of variables on the basis of expert knowledge. The development project efficiency evaluation allows to mitigate drawbacks of each method if they were used separately.

Second, the development project efficiency evaluation algorithm helps find a more nuanced project solution. If integral NPV turns to be higher than the predicted indicators, including all pessimistic and optimistic scenarios, the project efficiency is likely to exceed the benchmark. Such opportune investment in the project will raise profitability to a new level and the corporate value. Using the algorithm, it will be possible to consider the market risk associated with the price for one square meter of real estate. Therefore, once the market slowdown takes place, the company will not suffer from a dramatic lack of funds. This development project efficiency algorithm may be critically important in the following cases, i.e. a) experts seriously diverge on price forecasts; b) the project needs substantial investment, while having a protracted life cycle or weak viability; c) the company does not possess big capital stock or deals with construction and sale of real estate only.

Third, scenario analysis for purposes of the development project efficiency values may be constrained due to unavailable historical data on prices for a long-term period. The proposed algorithm may be unreasonable for risk assessment purposes, if the project is short-term and there is a low probability of events that may influence the price trend during the prediction period. 


\section{Table 1}

Quarterly forecast of average values for one square meter of real estate in New Moscow

\begin{tabular}{|c|c|}
\hline Period & Average price, RUB \\
\hline Q3 2017 & $86,540.32$ \\
\hline Q4 2017 & $87,191.54$ \\
\hline Q1 2018 & $87,842.76$ \\
\hline Q2 2018 & $88,493.98$ \\
\hline Q3 2018 & $89,145.2$ \\
\hline 042018 & $89,796.42$ \\
\hline Q1 2019 & $90,447.63$ \\
\hline Q2 2019 & $91,098.85$ \\
\hline Q3 2019 & $91,750.07$ \\
\hline 042019 & $92,401.29$ \\
\hline Q1 2020 & $93,052.51$ \\
\hline Q2 2020 & $93,703.73$ \\
\hline 032020 & $94,354.94$ \\
\hline 042020 & $95,006.16$ \\
\hline
\end{tabular}

Source : Authoring

Table 2

Assessment of the final adjustment for types of apartment and city district, RUB

\begin{tabular}{lllll}
\hline City district & \multicolumn{2}{l}{ Type of apartment } & \multicolumn{2}{c}{ Average price } \\
\cline { 2 - 4 } & One room & Two rooms & Three rooms & \\
\hline Kommunarka District & $74,546.9$ & $66,069.8$ & $58,685.5$ & $66,434.07$ \\
\hline New Moscow & $86,558.2$ & $84,254.7$ & $82,710.7$ & $84,507.87$ \\
\hline Adjustment for type of apartment (Kommunarka District) & 1.122 & 0.995 & 0.883 & - \\
\hline Final adjustment & 0.882 & 0.782 & 0.694 & - \\
\hline
\end{tabular}

Source : Authoring 
Figure 1

A conceptual model of the developer's activities

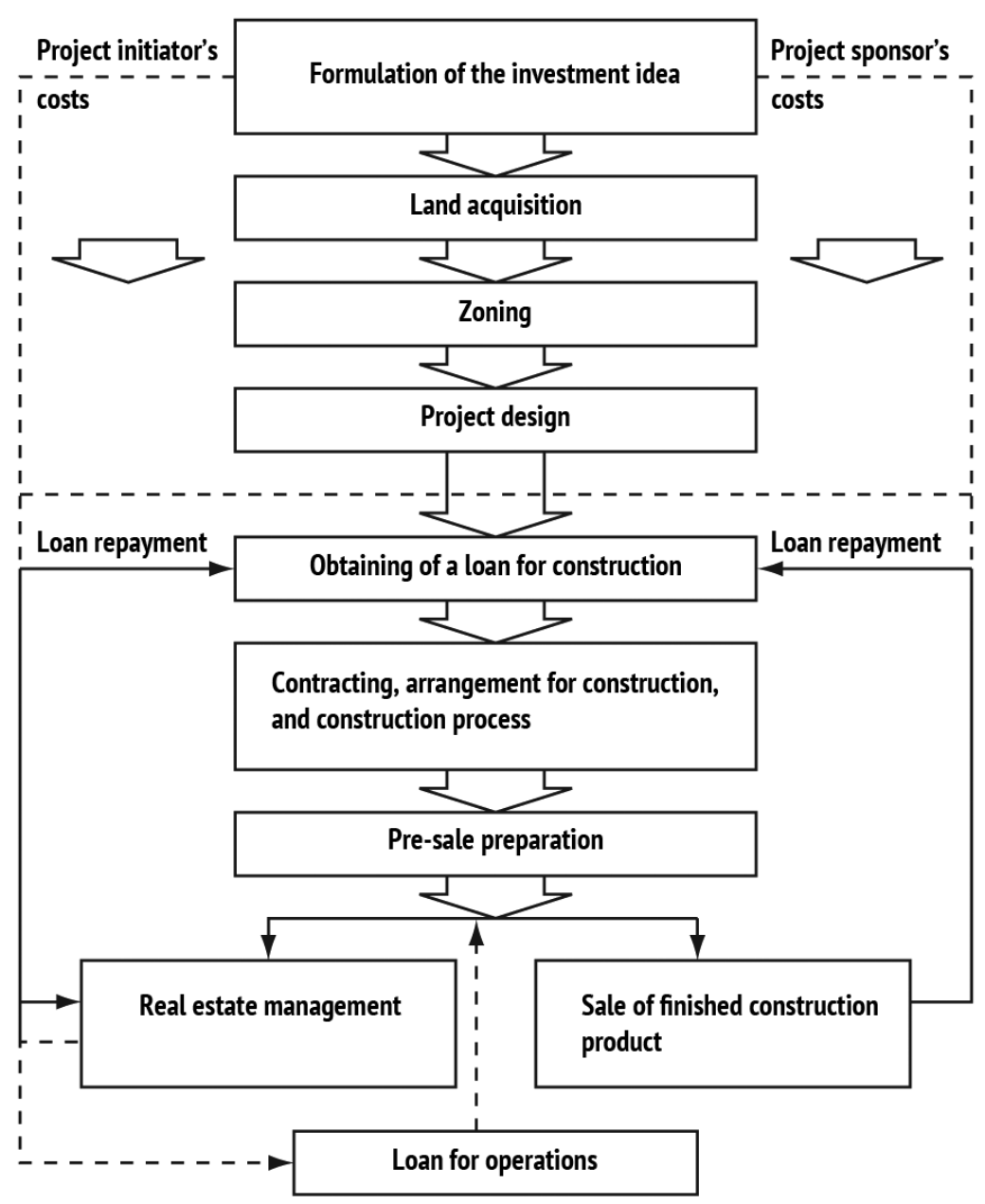

Source : Authoring

Figure 2

Forecast of prices for one square meter of real estate in the primary real estate market of New Moscow

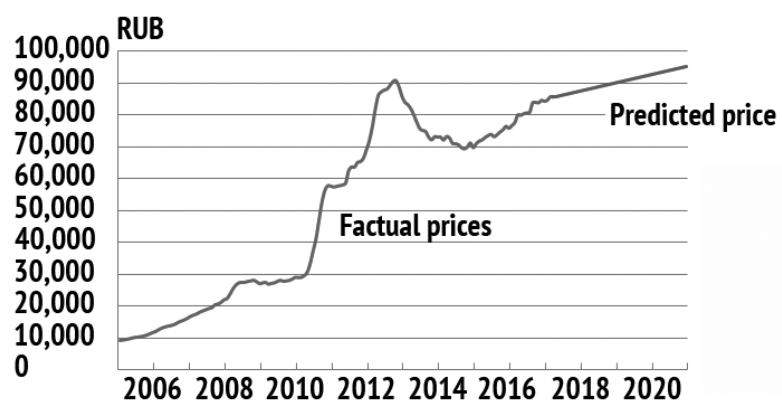

Source : Authoring

Please cite this article as: Filin S.A., Marushkina V.A. Specifics of Evaluating the Efficiency of Development Investment Projects. Digest Finance, 2018, vol. 23, iss. 2, pp. 150-162. https://doi.org/10.24891/df.23.2.150 
Figure 3

Setting of prediction intervals for average prices for one square meter of real estate in New Moscow

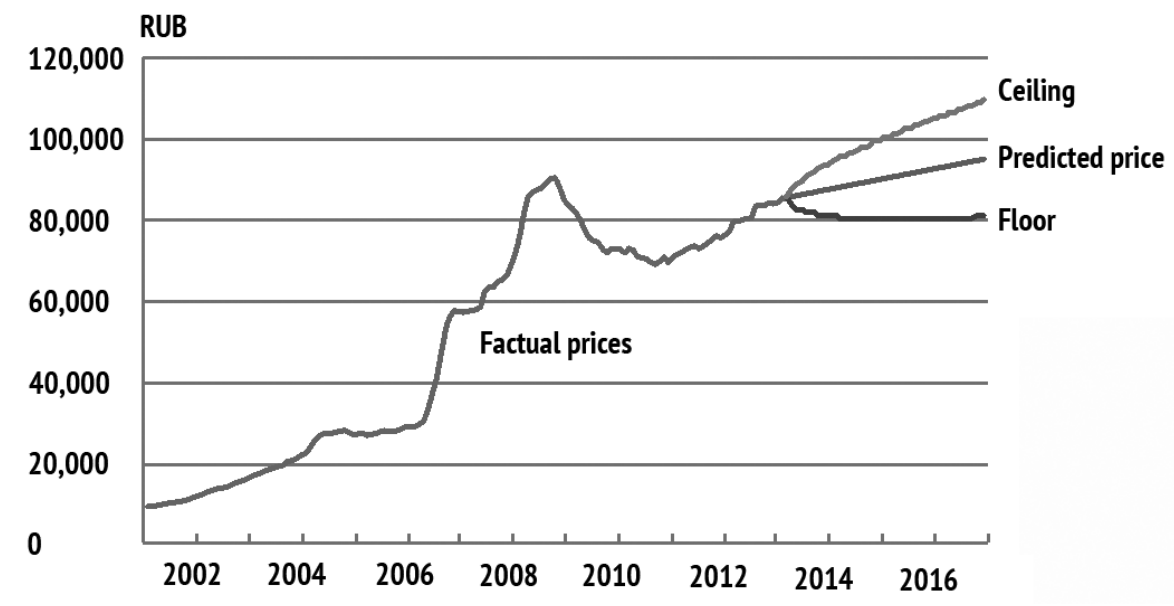

Source : Authoring

\section{Figure 4}

Comparison of simulation modeling results by the Monte Carlo method and primary extrapolation of prices for one square meter of real estate (Holt's method)

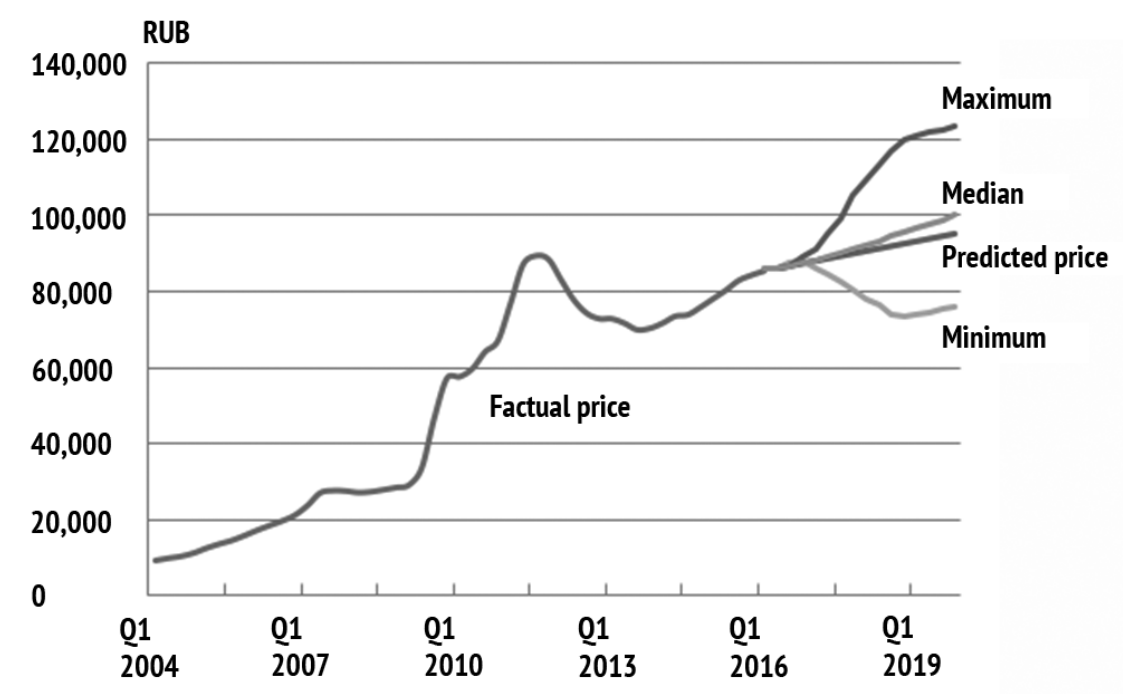

Source : Authoring 


\section{Figure 5}

The algorithm for evaluating the efficiency of developer projects

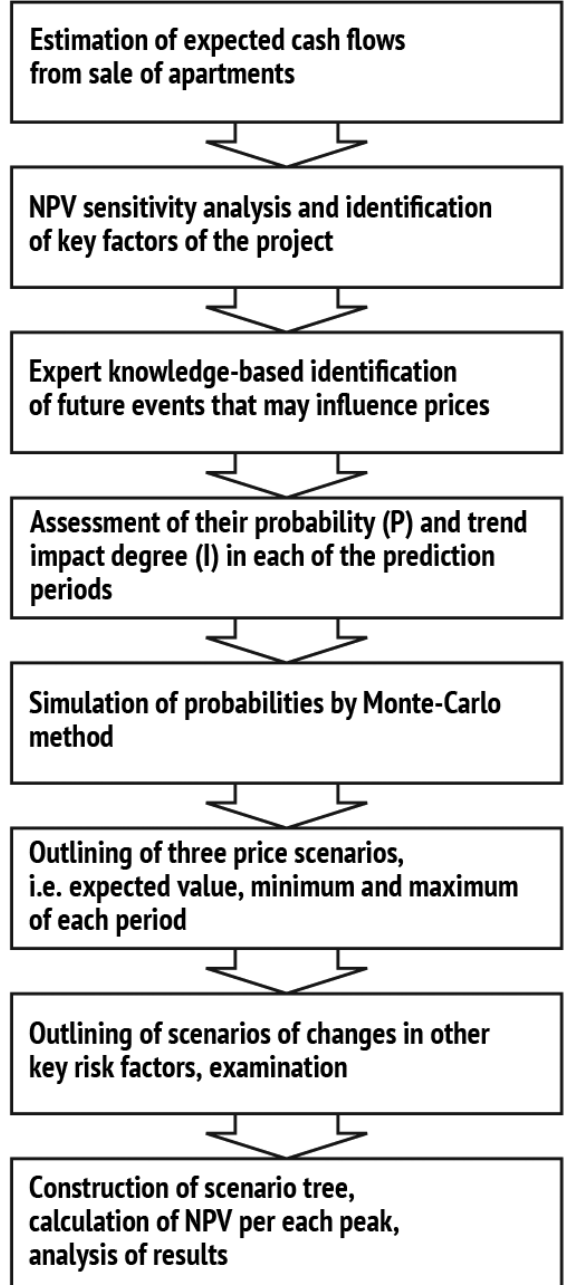

Source : Authoring

\section{References}

1. Dudchenko A.Yu. [Legal regulation of development]. Politematicheskii setevoi elektronnyi nauchnyi zhurnal Kubanskogo gosudarstvennogo agrarnogo universiteta, 2014, no. 100, pp. 1588-1600. (In Russ.) URL: http://ej.kubagro.ru/2014/06/pdf/34.pdf

2. Leus D.I. Razrabotka strategii innovatsionnoi i investitsionnoi politiki zhilishchno-kommunal'nogo khozyaistva sub"ekta Federatsii: monografiya [Developing the strategy for innovative and investment policy of housing and utilities infrastructure in the constituent entity of the Russian Federation]. Moscow, KnoRus Publ., 2014,216 p.

3. Golovanov E.B., Kiseleva V.A., Larin O.N. [Development as a special type of entrepreneurial activity in the real estate market]. Sovremennye problemy nauki i obrazovaniya, 2012, no. 2, pp. 28-35. (In Russ.) URL: https://science-education.ru/pdf/2012/2/61.pdf

4. Vadel' O.A. [Managing the investment project efficiency as per the cost approach concept]. Menedzhment $v$ Rossii i za rubezhom = Management in Russia and Abroad, 2011, no. 6, pp. 35-42. (In Russ.)

Please cite this article as: Filin S.A., Marushkina V.A. Specifics of Evaluating the Efficiency of Development Investment Projects. 
5. Arenkov I.A., Bichun Yu.A., Artsybyshev I.S., Gorbunov V.N. Upravlenie kompaniyami: restrukturizatsiya i razvitie developerskikh proektov: monografiya [Governance of companies: Restructuring and promoting developer projects: a monograph]. St. Petersburg, St. Petersburg State University of Economics Publ., 2016, p. 167.

6. Beloborodov R.S. [Development as an effective management system construction and investment projects]. Sovremennye tekhnologii upravleniya = Modern Management Technology, 2011, no. 2, pp. 16-22. (In Russ.)

7. Dudin M.N., Lyasnikov N.V., Sekerin V.D., Gasanbekov S.K. [Development as the effective management system of the investment construction project]. Ekonomika i predprinimatel'stvo = Journal of Economy and Entrepreneurship, 2014, no. 12-2, pp. 879-885. (In Russ.)

8. Kallaur G.Yu., Papikyan L.M. [Urban land development as part of investment and construction projects implementation]. Ekonomika stroitel'stva = Economics of Construction, 2016, no. 2, pp. 30-36. (In Russ.)

9. Fedotova M.A., Tazikhina T.V., Bakulina A.A. Development $v$ nedvizhimosti: monografiya [Development in real estate: a monograph]. Moscow, KnoRus Publ., 2010, 264 p.

10. Kochkin V. Effektivnyi development [Effective development]. Moscow, Rossiiskii pisatel' Publ., 2012, 336 p.

11. Kushchenko V.V. Development. Sovremennaya kontseptsiya razvitiya nedvizhimosti [Development. The modern concept for the future of real estate]. Moscow, Norma Publ., 2015, 367 p.

12. Lazarev O.V. [The real estate development concept in the Russian law]. Molodoi uchenyi = Young Scientist, 2015, no. 8, pp. 739-744. (In Russ.)

13. Ekenta Chukwuemeka. Application of Capital Asset Pricing Model (CAPM) on Real Property Investment in Nigeria. International Journal of Business \& Law Research, 2016, vol. 4, iss. 1, pp. 56-62.

14. Gardner E.S. Exponential Smoothing: The State of the Art. Part II. International Journal of Forecasting, 2006, vol. 22, iss. 4, pp. 637-666. URL: https://doi.org/10.1016/j.ijforecast.2006.03.005

15. Koehler A.B., Hyndman R.J., Snyder R.D. Prediction Intervals for Exponential Smoothing Using Two New Classes of State Space Models. Journal of Forecasting, 2005, vol. 24, iss. 1, pp. 17-37.

URL: https://doi.org/10.1002/for.938

16. Sternik G.M., Sternik S.G. [Evaluation of the mid-market investment returns in real estate development when forecasting the housing market]. Problemy prognozirovaniya = Problems of Forecasting, 2017, no. 2, pp. 106-116. (In Russ.)

17. Pupentsova S.V. Ob ispol'zovanii metoda Monte-Karlo pri otsenke investitsii v nedvizhimosti. V kn.: Rynok nedvizhimosti kak sfera investitsii [On the use of the Monte Carlo method in evaluating real estate investment. In: Real estate market as an area for investment]. St. Petersburg, Saint Petersburg State University of Engineering and Economics Publ., 2005, pp. 151-158.

\section{Conflict-of-interest notification}

We, the authors of this article, bindingly and explicitly declare of the partial and total lack of actual or potential conflict of interest with any other third party whatsoever, which may arise as a result of the publication of this article. This statement relates to the study, data collection and interpretation, writing and preparation of the article, and the decision to submit the manuscript for publication. 